Article

\title{
Environmental Activity of Mining Industry Leaders in Poland in Line with the Principles of Sustainable Development
}

\author{
Justyna Woźniak (D) and Katarzyna Pactwa * \\ Faculty of Geoengineering, Mining and Geology, Industrial and GeoEconomics Division, Wroclaw University of \\ Science and Technology, Na Grobli 15, 50-421 Wroclaw, Poland; justyna.wozniak@pwr.edu.pl \\ * Correspondence: katarzyna.pactwa@pwr.edu.pl; Tel.: +48-71-320-6851
}

Received: 26 July 2017; Accepted: 18 October 2017; Published: 1 November 2017

\begin{abstract}
As mining companies reveal more and more public information about themselves, the behaviour fosters a better image. This article aims to present two industry leaders in the context of environmental requirements they have met (status at the end of 2015), acting in compliance with the general principles of a socially responsible business. The choice of KGHM (Kombinat Gorniczo-Hutniczy Miedzi) companies (copper ores and other accompanying elements) CG PGE (Capital Group Polska Grupa Energetyczna S.A.) (lignite) was dictated by their significant share in the mining industry in Poland. The environmental aspects of the integrated monthly reports were listed and grouped in detail in accordance with the applicable Global Reporting Initiative (GRI) and GRI G4 Mining and Metals guidelines. The values of environmental indicators have been analysed over the years, including inter alia data concerning gas emissions, that is, $\mathrm{CO}_{2}, \mathrm{SO}_{\mathrm{x}}$, $\mathrm{NO}_{\mathrm{x}}, \mathrm{PM}$ or generated waste and sewage. Also, with regard to the environmental aspect of the work, energy consumption in companies is presented together with the characteristics of the fuel balance. The final part of the article compares the value of the revenues to the budgets of local government units (communes) from the operating fee paid by entrepreneurs and expenditures of these municipalities on environmental protection, as additional support by these entities (2013-2015).
\end{abstract}

Keywords: corporate social responsibility; environmental indicators; sustainability reports; mining industry; Poland

\section{Introduction}

Mining entrepreneurs are very concerned about obtaining positive reception with regard to their activity from the local community, authority or non-governmental organizations. Making the company's financial and non-financial data public can contribute to this. Practice shows that the presentation of non-financial data is included in integrated reporting, that is, compiling financial and non-financial data within a single document. Non-financial data referred to the aforementioned concern, namely, environmental issues. Environmental aspects such as energy, emissions, biodiversity, sewage and waste, and so forth, are in accordance with the specific guidelines of the Global Reporting Initiative (GRI) - annual reporting of sustainability [1,2], relating to corporate social responsibility. In this article, issues related to the natural environment will be discussed, including the way and scope of reporting information on this subject in integrated reports in the extractive industries. The data will include two mining companies, KGHM (Kombinat Gorniczo-Hutniczy Miedzi) and PGE (Polska Grupa Energetyczna S.A.), who in the author's opinion represent "responsible mining" [3,4]. Preparing integrated reports has been obligatory since January 2017 for large companies in the EU (according to Directive 2014/95/EU [5]). These are companies that fulfil the criterion of number of employees (500 persons for public interest entities required under the Directive to extend non-financial 
information) and balance sheet total ( $>20$ million EUR) or net income ( $>40$ million EUR). The choice of the issue was dictated by the key challenges facing mining enterprises, that is, environmental management and acceptance of the local community in regard to business. Reporting on the basis of the principles of corporate social responsibility (CSR) is one of the steps to improve the image of companies with a strategic contribution in the national economy, fostering better relationships between companies and their employees, the local community and the state administration at the municipal/local level. The aim of the article is to compare the scope of published reports and to analyse changes in the values of selected indicators including, among others, emissions of gases and dust, and quantities of generated waste or energy consumed over several years. Staying in the environmental convention, the article shows how the analysed companies subsidize the municipal budgets as part of their revenues-the source of which is the mining fee under the conducted mining operations.

\section{Data Reporting Conception According to CSR, Process of Evolution}

The development of reporting conception of corporate social responsibility is a dynamic process described, for example, by [6-12], based on a number of guidelines and standards. There is abundant literature on CSR reporting generally [13], CSR reporting in the mining industry [14-18], drivers for CSR reporting in for-profit businesses [19-21], failures and challenges of CSR reporting [22,23], as well as the discussion of a gap between disclosure and performance [24-26]. Directive 2014/95/EU clearly outlines the sources of initiatives/standards/guidelines useful for the preparation of this type of report. It emphasizes that the entities covered by the obligation of reporting may be based on national and European framework principles, that is, the Eco-Management and Audit system (EMAS), the international initiative of the United Nations (UN) Global Compact, the UN guidelines involving business and human rights, implementing UN frameworks, the Organization for Economic Cooperation and Development (OECD) guidelines for multinational enterprises, ISO 14001 and 26000 standards, reporting rules represented by International Integrated Reporting Council (IIRC), trilateral declaration of rules of the International Labour Organization (ILO), Global Reporting Initiative (GRI) and other recognized international framework rules. As mentioned above, the guidelines presented by GRI are the most widespread standard of reporting, inter alia, for non-financial data [27]. GRI is a non-governmental international and non-profit organization, based on a network of stakeholders, which has operated since 1997 in the United States. The fourth generation of guidelines (G4) has been valid since 2013. Meanwhile, sector guidelines have been developed for 10 sectors, including, inter alia, Mining and Metals (MM1-MM10), which can be used. In the authors' opinion, they should be regarded as complementing the content of the integrated company reports. The integrated CSR report becomes an opportunity to promote by publicizing information on additional social and environmental activities beyond the core business activities. The reporting trend can be a way to improve the perception of the mining industry as environmentally friendly to the companies and the public. It is assessed [28] that companies in the mining industry should include CSR strategies in their corporate governance policy at the start of mining activities. It is advisable to formulate clear rules for the development and shape of social awareness about the impact of mining on the life of the local population [29].

Profound changes have been noted in CSR reporting in the recent years. We are facing a significant increase in the number of reports produced and published by companies and other organizations in Poland. Integrated reports appear inside the unit or are implemented by external companies. Recently, leading audit firms have willingly offered cooperation in this area. Prepared reports are made public (written form, video files) and available on the company's website. This is particularly important for the Polish mining and energy industry in times of political uncertainty, numerous media attacks and unfavourable public opinion. 


\section{The Choice of Analysed Companies' Basic Information with Reference to CSR}

The analysed entities actively operate in a social-environmental zone, in line with the principles of CSR. Paying attention to this very fact shows that Poland, as an EU member, favours the mining sector even though it is criticised for, among other things, the energy mix based to a large extent on coal. It is worth noting, however, that it does not demonstrate its ignorance and reluctance to diversify energy sources, but rather its skilful use of native wealth being, among others, coal. This is in accordance with world standards, considering the principles of CSR [11].

KGHM Polska Miedz (KGHM) is a company that for many year has dealt with mining (underground exploitation) and processing of copper ores coming from one of the largest deposits in Europe, located in Southwest Poland. Since 1961, it has functioned as Kombinat Gorniczo-Hutniczy Miedzi (English: Copper Smelting-Mining Combine) in Lubin (formerly Zakłady Gornicze Lubin) being one of the investors and coordinators of construction works, leading to the discovery and documenting of the "New Copper Field" [30,31]. Creation of smelting-mining complex for copper is a chance taken for economic development of the region. At the same time, the investment was related to the impact on the natural environment in the form of terrain deformation, discharge of mineralised water from mine drainage and smelting waste, waste storage (including flotation waste) and emissions of gas and particulate pollutants. In the 1970s, KGHM created its own environment protection services. Furthermore, Ministerial Environment Protection Commission LGOM (Polish: Legnicko-Glogowski Okreg Miedziowy; English: Legnica-Glogow Copper District), working towards environment protection and health of the inhabitants was launched by the Minister of Heavy Industry. Subsequent years of company activity brought along a decrease in the unbeneficial impact of industrial objects on the environment [32]. Currently, KGHM as an enterprise maintains a leading spot in the rankings of the largest companies in Poland (List of 500 of Rzeczpospolita magazine) and in Eastern-Central Europe (Coface CEE Top 500). It was also awarded in the contest of Philanthropy Leaders in Poland. Acting in accordance with the principles of sustainable development, it publishes integrated reports in line with the guidelines in place (the latest report for year 2015 was elaborated on the basis of G4 guidelines), as well as belonging to RESPECT Index [4] or UN Global Compact (membership since 2 March 2015; current status: lack of communication resulting from non-provision of report within the deadline of 2 March 2016). At the end of 2015, the company accepted the Corporate Social Responsibility Strategy for the years 2015-2020 [33].

Capital Group Polska Grupa Energetyczna S.A. (CG PGE) has implemented a broad structure of actions in the following areas: extraction of lignite, production of electricity and heat, distribution and sales. PGE GiEK (Polska Grupa Energetyczna S.A.-Gornictwo i Energetyka Konwencjonalna S.A.) is one of the concerns which comprise CG PGE and, at the same time, an industry leader in extraction of lignite by means of opencast method (share in national market of this raw material amounts to over 77\%; three other mines operate on the extraction market). CG PGE is engaged in a number of initiatives compliant with CSR, among others, being a member of UN Global Compact (since 2008), RESPECT Index (since 2011), strategic partner of Responsible Business Forum (since 2015), participating in the national project of Vision of Sustainable Development for Polish Business 2050 following the initiative of World Business Council for Sustainable Development. The extractive Branch of PGE GiEK S.A., that is, the Belchatow lignite mine, is considered a strong pillar of the Polish economy, and was assigned the title "the best investor in the Lodz region". CG PGE responsibly and consciously shapes the relationship between an economic increase and care for natural ecosystems. For this reason, it minimizes the negative impact on the natural environment related to noise emissions through waste management, sewage management and rational and effective uses of water resources. This is confirmed by an implemented and binding System of Environmental Management, compliant with the requirements of the PN-EN ISO 14001 norm. Moreover, accredited laboratories are in place in the scope of quality management system and research methods of coal, slag and ash in line with the PN-EN ISO/IEC 17025:2005 norm. The company is strongly engaged in reclamation works (new forest, water, recreation complexes) and protects biodiversity. Local communities, authorities of local governments 
(communes) and non-governmental organizations are consulted with each time for plans and new investments [34].

Respect Index (RI) is a stock market indicator that was the first one in Central-Eastern Europe to be created in Poland, and which was formed by companies managed in a responsible and sustainable way. It was launched at the end of 2009 (it consisted at the time of 16 companies, but as of 26 June 2017, this number has grown to 24), and it is said to assess the economic conditions of Polish companies with the highest ratings noted on the national regulated market of the Warsaw Stock Exchange. This assessment takes place in the scope of economy, ecology and society and the functioning of a given company in these areas, perfectly matching the idea of corporate social responsibility (CSR). A summary of all the emissions of RI listings reveals the participation of mining industry leaders in Poland. KGHM has participated in creating RI values on an ongoing basis since the beginning of the listings, constituting more than an $8 \%$ share of the index portfolio. CG PGE has created a portfolio value of RI continuously since 2011 (approx. 8\%).

\section{Exploration of Integrated Reports of Companies within the Environmental Dimension}

While analysing reports of the aforementioned companies, the focus was placed on the documents describing the activities of the companies in 2015. The article considered that the environmental data in the reports are reliable. Theoretical considerations [35] about the risk of disclosure of environmental data by entrepreneurs and their impact on stakeholders were not considered. Reports from the previous years of business activity were downmarket, smaller in terms of volume, where only mentions of the GRI could be found and which contained no explicit description of the indicators. This was due to the development of the guidelines and the first attempts to apply, among others, 10 rules defined by the Global Compact.

The choice of the environmental category in mining industry policy was dictated by the most important challenge for the management of the environment and the acceptance of the local community that has taken place in recent years. These data have been published in the International Council of Metals and Mining (ICMM) reports, based on surveys conducted among some 300 mining companies under the title "The role of mining in national economies" and "Research on company-community conflict", where a number of challenges facing companies in the mining industry as part of the CSR policy were presented. Priority areas include environmental and social issues, government regulations, project economics (prices and cost minimization), water management, acquisition of exploration, financing of investments, human resources management, acquisition of concessions for mining, sustainable development and the need to implement new technologies [36].

The G4 GRI environmental category covers a variety of aspects: material; raw materials; energy; water; biodiversity; emissions; waste and sewage; products and services; compliance with regulations; transport; general issues; supplier environmental assessment, and; complaints concerning environmental issues. Environmental reports from the leaders (for 2015) have been analysed, and a scheme has been developed that illustrates which indicators are implemented by individual companies in accordance with G4 (Figure 1). Reports have been verified in terms of guidelines contained in GRI G4 Mining and Metals (GRI G4 M \& M) [37,38]. The following diagram shows the common parts of the environmental guidelines for the two leaders in the Polish extractive industry, which are part of the content of the reports. 


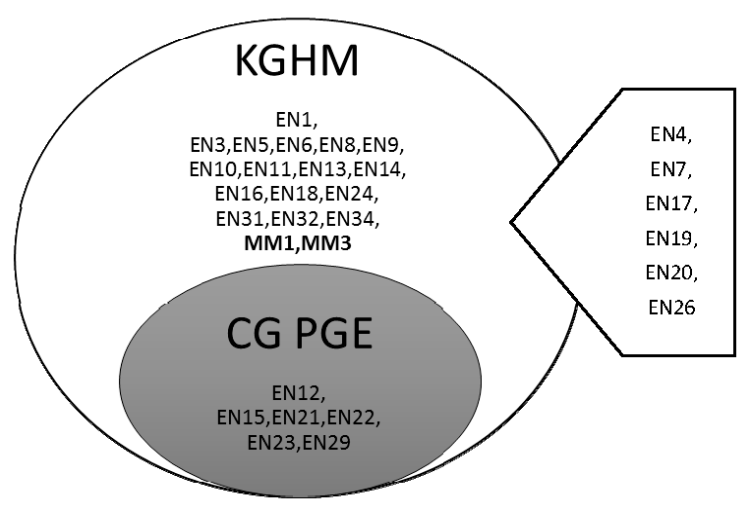

Figure 1. Environmental indicators of Global Reporting Initiative (GRI) occurring in the integrated reports of KGHM (Kombinat Gorniczo-Hutniczy Miedzi) and CG PGE (Capital Group Polska Grupa Energetyczna S.A.) for 2015 [33,34].

Only six indicators (EN12-EN29) from among 36 of the four aspects (including biodiversity, emissions, waste, sewage and regulatory compliance) are shared by leaders as a common part. The more extensive environmental report is one elaborated by KGHM (16 indicators, i.e., EN1-EN34), which includes two out of three GRI G4 M \& M (MM1, MM3) environmental guidelines. Neither of the analysed companies analyses EN4-EN26 and MM2, which could form part of an integrated report with regard to the activity and impact on the environment. The G4 reporting guidelines also include two environmental indicators, EN25 and EN28, but these issues do not fit into the specifics of the mining industry. Description of environmental indicators based on GRI are shown in Table 1.

Table 1. Description of environmental indicators based on GRI divided into different aspects.

\begin{tabular}{|c|c|c|}
\hline Aspect & Signature & Explanation \\
\hline \multirow[b]{2}{*}{ Biodiversity } & MM1 & $\begin{array}{c}\text { Amount of land-owned or leased, and managed for production activities or } \\
\text { extractive use — disturbed or rehabilitated }\end{array}$ \\
\hline & MM2 * & $\begin{array}{l}\text { The number and percentage of total sites identified as requiring biodiversity } \\
\text { management plans according to stated criteria, and the number (percentage) } \\
\text { of those sites with plans in place }\end{array}$ \\
\hline $\begin{array}{c}\text { Emissions, } \\
\text { effluents, waste }\end{array}$ & MM3 & $\begin{array}{l}\text { Total amounts of overburden, rock, tailings, and sludge and their } \\
\text { associated risks }\end{array}$ \\
\hline Materials & EN1 & Materials used by weight or volume \\
\hline \multirow{8}{*}{ Energy } & EN3 & Energy consumption within the organization \\
\hline & $\mathrm{EN} 4 *$ & Energy consumption outside of the organization \\
\hline & EN5 & Energy intensity \\
\hline & EN6 & Energy intensity \\
\hline & EN7 * & Reductions in energy requirements of products and services \\
\hline & EN8 & Total water withdrawal by source \\
\hline & EN9 & Water sources significantly affected by withdrawal of water \\
\hline & EN10 & Percentage and total volume of water recycled and reused \\
\hline \multirow[b]{2}{*}{ Biodiversity } & EN11 & $\begin{array}{c}\text { Operational sites owned, leased, managed in, or adjacent to, protected areas } \\
\text { and areas of high biodiversity value outside protected areas }\end{array}$ \\
\hline & EN12 & $\begin{array}{c}\text { Description of significant impacts of activities, products, and services on } \\
\text { biodiversity in protected areas and areas of high biodiversity value outside } \\
\text { protected areas }\end{array}$ \\
\hline
\end{tabular}


Table 1. Cont.

\begin{tabular}{|c|c|c|}
\hline Aspect & Signature & Explanation \\
\hline & EN13 & Habitats protected or restored \\
\hline & EN14 & $\begin{array}{l}\text { Total number of IUCN Red List species and national conservation list species } \\
\text { with habitats in areas affected by operations, by level of extinction risk }\end{array}$ \\
\hline \multirow{7}{*}{ Emissions } & EN15 & Direct greenhouse gas (GHG) emissions (scope 1) \\
\hline & EN16 & Energy indirect greenhouse gas (GHG) emissions (scope 2) \\
\hline & EN17* & Other indirect greenhouse gas (GHG) emissions (scope 3) \\
\hline & EN18 & Greenhouse gas (GHG) emissions intensity \\
\hline & EN19* & Reduction of greenhouse gas (GHG) emissions \\
\hline & EN20* & Emissions of ozone-depleting substances (ODS) \\
\hline & EN21 & NOx, SOx, and other significant air emissions \\
\hline \multirow{4}{*}{$\begin{array}{l}\text { Effluents and } \\
\text { waste }\end{array}$} & EN22 & Total water discharge by quality and destination \\
\hline & EN23 & Total weight of waste by type and disposal method \\
\hline & EN24 & Total number and volume of significant spills \\
\hline & EN26* & $\begin{array}{l}\text { Identity, size, protected status, and biodiversity value of water bodies and } \\
\text { related habitats significantly affected by the organization's discharges of } \\
\text { water and runoff }\end{array}$ \\
\hline Compliance & EN29 & $\begin{array}{l}\text { Monetary value of significant fines and total number of non-monetary } \\
\text { sanctions for non-compliance with environmental laws and regulations }\end{array}$ \\
\hline Overall & EN31 & Total environmental protection expenditures and investments by type \\
\hline $\begin{array}{l}\text { Supplier } \\
\text { Environmental } \\
\text { Assessment }\end{array}$ & EN32 & Percentage of new suppliers that were screened using environmental criteria \\
\hline $\begin{array}{l}\text { Environmental } \\
\text { Grievance } \\
\text { Mechanisms }\end{array}$ & EN34 & $\begin{array}{l}\text { Number of grievances about environmental impacts filed, addressed, and } \\
\text { resolved through formal grievance mechanisms }\end{array}$ \\
\hline
\end{tabular}

* Omitted environmental aspects Source: [37,38]. Mining and Metals (MM); Environmental indicators (EN).

\section{Analysis of Selected Indicators in the Environmental Aspect-Discussion}

The next step was to analyse the value of several indicators in the environmental aspect. The basic criterion for their selection was the availability and readability of the information provided in the integrated reports. Since the objective is to compare the values of indicators, only common parts (i.e., those that the two companies have in common) are included. Integrated reports from the years 2013-2015 were the source materials.

The first indicator whose values were identified both in the KGHM PM SA and CG PGE reports was the emission factor: carbon dioxide $\left(\mathrm{CO}_{2}\right)$; sulphur oxides $\left(\mathrm{SO}_{\mathrm{x}}\right)$; nitrogen $\left(\mathrm{NO}_{\mathrm{x}}\right)$, and; particulate matter (PM). Relative values of the indicators were analysed. In the case of KGHM, the mass (Mg) of the emitted compounds was referred to the amount of produced electrolytic copper expressed in $\mathrm{Mg}$, whereas in the case of PGE, the data were referred to the produced energy expressed in MWh, taking into account both electricity and heat production. The emission factor values are shown in Figure 2a,b. 


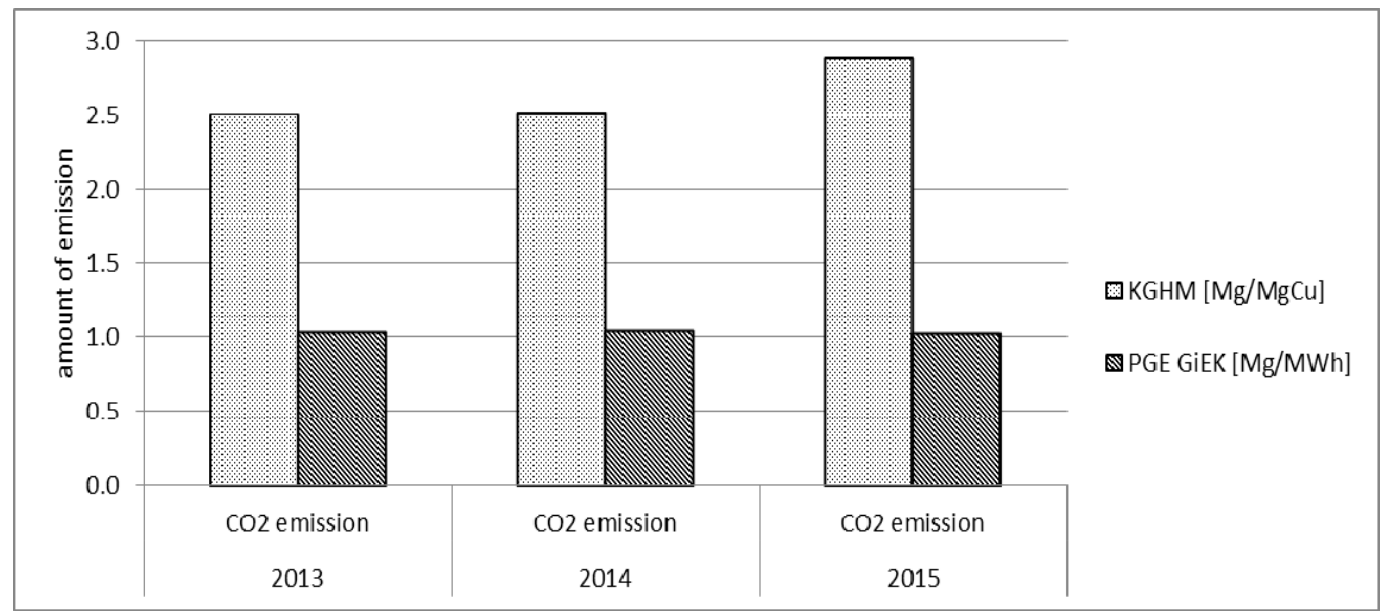

(a)

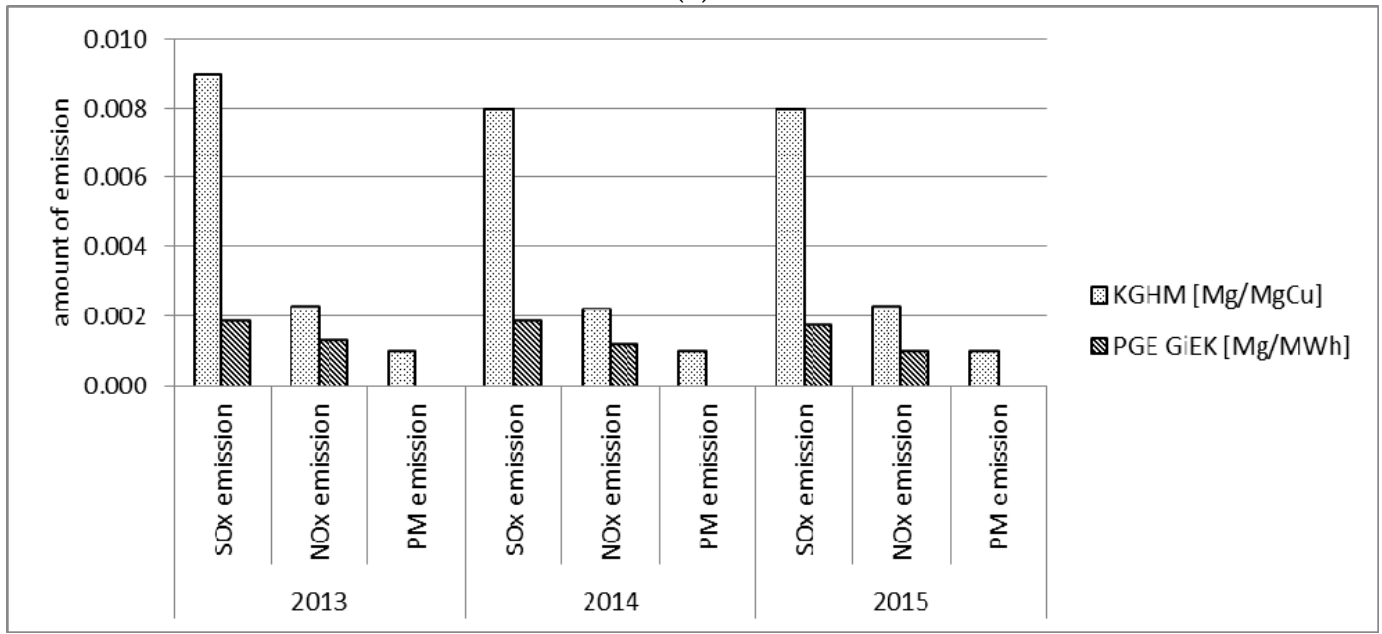

(b)

Figure 2. Comparison of values of emission factors in KGHM and PGE: (a) $\mathrm{CO}_{2}$; (b) $\mathrm{SO}_{\mathrm{x}}, \mathrm{NO}_{\mathrm{x}}, \mathrm{PM}$ (data source: $[33,34,39-42])$.

Emissions to the atmosphere are associated in KGHM primarily with the generation of electricity, as well as occurring at the metallurgical, refining and processing stages, for which HM Głogów, HM Legnica and HM Cedynia-Walcownia remain responsible. In addition, they are present in the transport stage of materials, products and waste. PGE's emission sources are primarily power stations and power plants (conventional energy). Changes in the amounts of emitted compounds are shown in Table 2.

Table 2. Changes in the volume of emitted compounds (emission factors) in the years 2013/2014 and 2014/2015.

\begin{tabular}{ccccccccc}
\hline \multirow{2}{*}{$\begin{array}{c}\text { Years/Time } \\
\text { Interval }\end{array}$} & \multicolumn{2}{c}{$\mathrm{CO}_{2}$} & \multicolumn{2}{c}{$\mathrm{SO}_{\mathbf{x}}$} & \multicolumn{2}{c}{ NO $_{\mathbf{x}}$} & \multicolumn{2}{c}{ PM } \\
\cline { 2 - 8 } & KGHM & $\begin{array}{c}\text { PGE } \\
\text { (GiEK) }\end{array}$ & KGHM & $\begin{array}{c}\text { PGE } \\
\text { (GiEK) }\end{array}$ & KGHM & $\begin{array}{c}\text { PGE } \\
\text { (GiEK) }\end{array}$ & $\begin{array}{c}\text { KGHM } \\
\text { (GiEK) }\end{array}$ & $\begin{array}{c}\text { PGE } \\
\text { (GiEK) }\end{array}$ \\
\hline $2013-2014$ & $\uparrow 0.56 \%$ & $\uparrow 0.48 \%$ & $\downarrow 11.11 \%$ & $\uparrow 1.08 \%$ & $\downarrow 4.35 \%$ & $\downarrow 9.92 \%$ & $\begin{array}{c}\text { no } \\
\text { change }\end{array}$ & $\begin{array}{c}\text { no } \\
\text { change }\end{array}$ \\
\hline $2014-2015$ & $\uparrow 14.46 \%$ & $\downarrow 1.52 \%$ & $\begin{array}{c}\text { no } \\
\text { change }\end{array}$ & $\downarrow 6.81 \%$ & $\uparrow 4.54 \%$ & $\downarrow 15.31 \%$ & $\begin{array}{c}\text { no } \\
\text { change }\end{array}$ & $\downarrow 14.66 \%$ \\
\hline
\end{tabular}

Source: [33,34,39-42]. PGE GiEK (Polska Grupa Energetyczna S.A.—Gornictwo i Energetyka Konwencjonalna S.A.). $\uparrow$ : increase, $\downarrow$ : decrease. 
Compared to the previous year, most of the changes in emissions did not exceed $10 \%$, except for the year 2014, when KGHM reported a greater drop in sulphur oxide emissions, and in 2015, when KGHM noted increased carbon dioxide emissions and PGE noted drops in nitrogen oxides and particulate matter. In integrated reports, entrepreneurs declare their intent to comply with environmental standards by modernizing installations targeted at environment protection and making new investments in this area. This is confirmed by the values of emission factors that are stable or are experiencing slight fluctuations. The increase in $\mathrm{CO}_{2}$ emissions by KGHM (the biggest negative change in emissions-Table 2) could be due to the company's development and launch of new gas-steam units. This is a direction of change that is beneficial to a company pursuing energy independence.

The weight of hazardous and non-hazardous waste according to the treatment/disposal method has been compared successively. The values shown in Figure 3 are absolute values expressed in $\mathrm{Mg}$ for KGHM and PGE (GiEK), respectively.

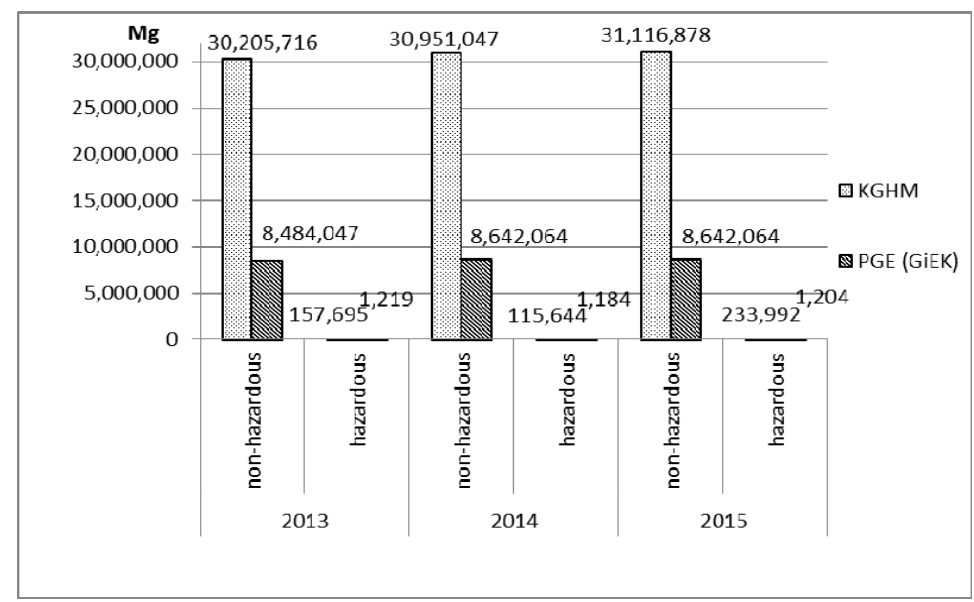

Figure 3. Total weight of waste disposed of by KGHM and PGE (source: [33,34,39-42]).

In KGHM, the disposal of extractive waste resulting from the enrichment of ores takes place at the Iron Bridge facility. This facility is being expanded and works to improve the technology of waste disposal.

The most significant changes in the amount of waste occurred in KGHM and involved waste classified as hazardous. This category of waste encompasses, among other things, sulphur and sulfuric acids, dust from waste gases, sludge and filter cakes from the treatment of waste gases, and sludge containing dangerous substances resulting from non-biological treatment of industrial waste water (Journal of Laws of 2014, item 1923.) In 2014, there was a decrease in waste disposal by over $26 \%$ compared to 2013, and it doubled in 2015 (an increase of over 100\% compared to 2014) (Table 3). The change in the amount of hazardous waste was not associated with a significant $(>10 \%)$ change in the share of waste recovered from landfills. In 2014 it was 70\% to $30 \%$, while in 2015 , it was $60 \%$ to $40 \%$, respectively. In PGE, waste is generated mainly in the combustion process and the waste gas treatment processes. Over the last three years, there has been no change in the amount of waste which would exceed $3 \%$.

Table 3. Changes in the amount of waste disposed of by mining companies in the years $2013 / 2014$ and $2014 / 2015$.

\begin{tabular}{ccccc}
\hline \multirow{2}{*}{$\begin{array}{c}\text { Years/Time } \\
\text { Interval }\end{array}$} & \multicolumn{2}{c}{ Non-Hazardous Waste } & \multicolumn{2}{c}{ Hazardous Waste } \\
\cline { 2 - 5 } & KGHM & PGE (GiEK) & KGHM & PGE (GiEK) \\
\hline $2013-2014$ & $\uparrow 2.47 \%$ & $\uparrow 1.83 \%$ & $\downarrow 26.67 \%$ & no change \\
$2014-2015$ & $\uparrow 0.54 \%$ & $\downarrow 2.87 \%$ & $\uparrow 102.34 \%$ & $\uparrow 1.66 \%$ \\
\hline \multicolumn{3}{c}{ Source: [33,34,39-42]. }
\end{tabular}


In the case of sewage, changes in the amount of their discharge have been shown in Table 4.

Table 4. Changes in volume of effluents discharged by KGHM and PGE (GiEK) in the years 2013/2014 and 2014/2015.

\begin{tabular}{ccc}
\hline \multirow{2}{*}{ Years/Time Interval } & \multicolumn{2}{c}{ Effluents } \\
\cline { 2 - 3 } & KGHM & PGE (GiEK) \\
\hline $2013-2014$ & no change & $\downarrow 6.59 \%$ \\
$2014-2015$ & $\downarrow 19.54 \%$ & $\downarrow 2.88 \%$ \\
\hline \multicolumn{3}{c}{ Source: $[33,34,39-42]}$.
\end{tabular}

Both in the case of KGHM and PGE, the volume of wastewater discharged in subsequent years has decreased.

One of the aspects in the framework of energy analysis is energy (Table 1). Reports of the analysed companies have revealed the levels of total energy consumption by fuel type.

In the analysed period for KGHM (2011-2015), the amount of energy consumed increases while the structure of the fuel base changes (Figure 4). Natural gas has the largest share, about $44-53 \%$. Its importance is significantly increased (according to the strategy of the company in this respect). The share of coal, which constituted about $39 \%$ in 2011, decreased to $33 \%$ in 2015, which is similar to diesel, whose importance in the balance of consumption decreases from 15\% in 2011 to $11 \%$ in 2015. In this table, fuel oil with a share of about 1.5-2\% has been listed. KGHM uses energy from crude oil, liquefied petroleum gas (LPG), gasoline or ethane, but the share of these fuels, constituting $<1 \%$, has been omitted in the analysis. In addition, based on the above data, unit energy consumption in KGHM electrolytic copper production unit has been estimated: $19.17 \mathrm{GJ} / \mathrm{MgCu}(2015)$; 15.77 GJ/MgCu (2014), and; $15.90 \mathrm{GJ} / \mathrm{MgCu}$ (2013).

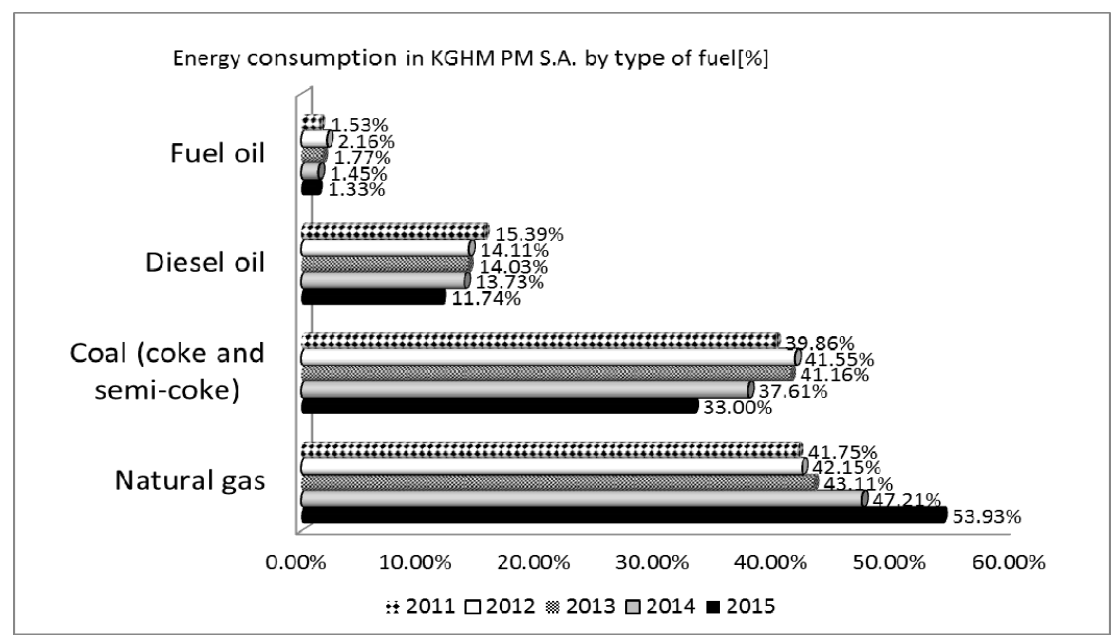

Figure 4. Energy balance in KGHM (data source: [33,41,42]).

Considering the energy consumption in PGE (GiEK), the situation is stable, that is, within the two analysed years, 2013-2014, the share of individual fuels did not change (Figure 5). The main fuel is coal: brown coal at about $72 \%$, and stone coal at about $24 \%$. The balance is supplemented by $1 \%$ of high-methane natural gas and $<1 \%$ share of fuel, that is, nitrogen-rich natural gas, fuel oil, diesel and petrol. Based on the level of extraction and total energy production in PGE (GiEK), its unit consumption level was set at GEiK as: 10.95 GJ/Mg (2014); 11.31 GJ/Mg (2013); 9.68 GJ/TWh (2014); $9.78 \mathrm{GJ} / \mathrm{TWh}(2013)$. 


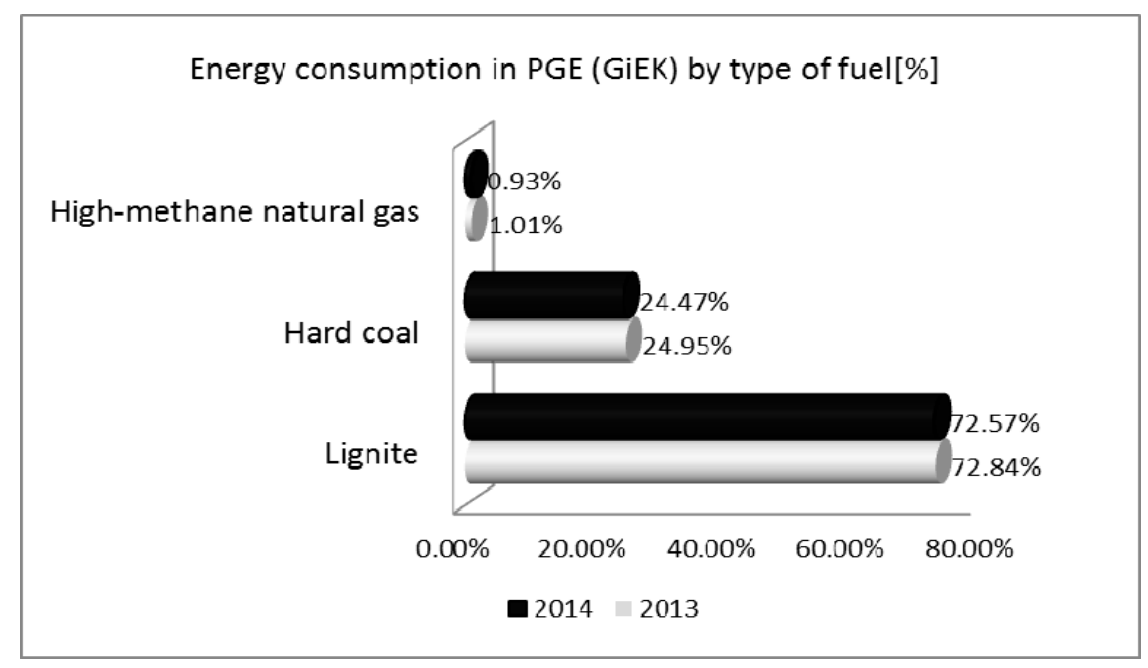

Figure 5. Energy balance in PGE (GiEK) (source: [39,40]).

The issue of biodiversity has been indicated. The KGHM PM SA integrated report states that the activity of a company's branches has had no significant negative impact on valuable natural species and sites (including Natura 2000). On the other hand, CG PGE conducts remediation work, contributing to the formation of forest and aquatic complexes where many species of animals and plants live.

\section{Importance of Mining Fee in the Budgets of the Commune}

By analysing the budgets of the communes in which coal and copper ores are being exploited, information on the size of the revenues of local government units was obtained. These revenues resulted from the mining fee, which, in light of the regulations in force [43], entrepreneurs in the mining industry in Poland are obligated to pay. Sixty percent of the mining fee (counted as the product of the mining volume and the unit rate attributed to the mineral) is the income of the commune, in which the activity is carried out, and $40 \%$ of it is the income of the National Fund for Environmental Protection and Water Management (NfFEPaWM). Since 2017, in connection with the planned establishment of a new institution (i.e., the Polish Geological Service (PSG)), the split of funds above $40 \%$ will be allocated at a rate of 35\% for PSG and 5\% for NfFEPaWM. In addition, as part of the establishment of PSG, proceeds from the mining fees of the richest communes in Poland will be additionally reduced (based on project assumptions).

The mining activities of the lignite PGE industry leader are carried out by two mines located in the area of five communes. Copper ore exploitation by KGHM covers nine communes and the city of Lubin. As of the end of 2015, not all of the communes mentioned above had income due to the mining fee, as the progress of exploitation fronts did not cover the areas of all communes. The table below shows the budgets of the communes that had income from mining operations in their area.

By analysing the revenues from the mining fee to the budgets of the communes in which the mines are located (Table 5), their percentage share in the total income scale was estimated (from about $1 \%$ to $33 \%)$. At the same time, it was shown how the selected leaders of the mining industry subsidize local government units and in which scope communes are working to protect the environment. Expenditures related to protection of the environment and municipal economy of the region account for $8 \%$ of the operating fee for KGHM and about $23 \%$ for PGE. In four communes, environmental expenditures repeatedly exceed revenues from mines. In the case of a commune in which PGE operates and in the case of two communes where exploitation of the deposits belonging to KGHM is conducted, it happens more often. Budget revenues from the mining fee of other minerals in the analysed communes are low (approx. 1-6\%), so they do not constitute a separate analysis. The expenditure of communes connected 
with municipal economy and environmental protection concern, inter alia, sewage management, water protection, waste management, maintaining cleanliness and order in a commune, maintenance of greenery, dealing with the consequences of natural disasters, lighting of streets, squares, and roads, other activities and other property expenses. Analysing the budgets of local government units, a number of difficulties related to the completeness of the documentation posted on the website of the Public Information Bulletin (which was created for the purpose of making public information publicly accessible in electronic form) have been encountered. One may notice chaos and lack of clear budgeting standards. Lack of standards and incompleteness of published data makes analysis difficult.

Table 5. The significance of the mining fee paid by the leaders in the budgets of communes in the years 2013-2015 (based on [11]).

\begin{tabular}{|c|c|c|c|c|c|c|c|}
\hline \multirow[b]{2}{*}{$\begin{array}{l}\text { Mining } \\
\text { Industry }\end{array}$} & \multirow[b]{2}{*}{ Commune } & \multicolumn{2}{|c|}{2013} & \multicolumn{2}{|c|}{2014} & \multicolumn{2}{|c|}{2015} \\
\hline & & $\begin{array}{l}\text { Share the } \\
\text { Mining Fee on } \\
\text { the Total } \\
\text { Revenues of } \\
\text { Communes }\end{array}$ & $\begin{array}{l}\text { Share the } \\
\text { Mining Fee on } \\
\text { the Expenses } \\
\text { Related to } \\
\text { Environment } \\
\text { Protection }\end{array}$ & $\begin{array}{l}\text { Share the } \\
\text { Mining Fee on } \\
\text { the Total } \\
\text { Revenues of } \\
\text { Communes }\end{array}$ & $\begin{array}{l}\text { Share the } \\
\text { Mining Fee on } \\
\text { the Expenses } \\
\text { Related to } \\
\text { Environment } \\
\text { Protection }\end{array}$ & $\begin{array}{l}\text { Share the } \\
\text { Mining Fee on } \\
\text { the Total } \\
\text { Revenues of } \\
\text { Communes }\end{array}$ & $\begin{array}{l}\text { Share the } \\
\text { Mining Fee on } \\
\text { the Expenses } \\
\text { Related to } \\
\text { Environment } \\
\text { Protection }\end{array}$ \\
\hline \multirow{4}{*}{ CG PGE } & Kleszczów & 0.16 & 0.54 & 0.12 & 0.64 & 0.12 & 0.28 \\
\hline & Szczerców & - & - & - & - & 0.03 & 0.23 \\
\hline & Rząśnia & - & - & - & - & 0.26 & 1.80 \\
\hline & Bogatynia & 0.07 & 0.47 & 0.06 & 0.33 & 0.06 & 0.34 \\
\hline \multirow{6}{*}{ KGHM } & Polkowice & 0.12 & 0.97 & 0.11 & 1.25 & 0.11 & 1.49 \\
\hline & Radwanice & 0.33 & 1.99 & - & - & 0.31 & 1.96 \\
\hline & Grębocice & 0.06 & 1.15 & 0.10 & 2.24 & 0.15 & 3.45 \\
\hline & Rudna & - & - & 0.01 & 0.08 & 0.04 & 0.25 \\
\hline & Lubin & - & - & - & - & 0.15 & 0.90 \\
\hline & Lubin C. & 0.01 & 0.22 & 0.01 & 0.14 & 0.01 & 0.12 \\
\hline
\end{tabular}

\section{Conclusions}

The policy of selected leaders in the mining industry in Poland is an example of promoting good practices within corporate responsibility of enterprises. Reporting of non-financial data according to the guidelines in force is a challenge for these companies, and since January of 2017, it has become a necessity among selected entities that meet the criteria of Directive 2014/95/EU. Analysis of the reports of KGHM and PGE has shown to what extent the activity of mining companies is extensive in terms of the environment. Based on the analysed examples, it has been stated that the company exploiting raw material using underground method implements better practices in the area of corporate responsibility of enterprises in the environmental dimension. In the prepared reports, the elements of environmental issues are described in detail by analysing a number of indicators (Figure 1). They are missing little to reach their full success; enriching reports on EN4-EN20 issues and GRI G4 Mining and Metal guidelines. CG PGE has a lot to catch up to do when it comes to good practices and how to incorporate them into the integrated report. This may be due to the broad activity of PGE in relation to KGHM or their implementation, rather a lack of skills or the method of estimation for reporting purposes. The lack of an estimation of typical mining GRI G4 M \& M indicators (MM1-MM3) raises concerns. This does not undermine the significance and high importance of this enterprise for the national economy, especially mining and power engineering. However, to be among the top leaders, one should not only report in accordance with the principles of corporate responsibility but also report in a complex manner, taking into account all environmental aspects (GRI, GRI G4 M \& M). In the opinion of the authors, it is important to improve the image of the mining industry as friendly to environment and society. The information contained in reports on energy consumption, gas emissions, waste, waste water and biodiversity is a good example of improving this image. Comparison of indicator values, included in the companies' reports, allowed the assessment of the entrepreneurs' care for the environmental condition of the mines, steel plants and power plants. It is also worth highlighting that the reports provided by KGHM PM and CG PGE are one of the few reports that allow us to compare the amount of gaseous emissions, the weight of stored waste and the energy 
consumption (in comparison, due to lack of data, LW Bogdanka conducting coal mining could not be found, among others). In addition, in view of the mining fee charged to the companies in question, which is used to finance the mining communities, it is worth mentioning that it increases their revenues by an average of $11 \%$ (maximum $33 \%$ ). Comparing these impacts to the community expenditures on the environment, it is clear that the fee is a large part of them. Furthermore, it can be devoted entirely to environmental investments, and sometimes they exceed those costs in certain communes.

Acknowledgments: This scientific work was financed within Statute Research Studies (order 0401/0201/16).

Author Contributions: Woźniak Justyna i Katarzyna Pactwa designed the study, all authors analyzed the results together and approved the final manuscript.

Conflicts of Interest: The authors declare no conflict of interest.

\section{References}

1. Brown, H.S.; de Jong, M.; David, L.L. Building Institutions Based on Information Disclosure: Lessons from GRI's Sustainability Reporting. J. Clean. Prod. 2009, 17, 571-580. [CrossRef]

2. Moseñe, J.A.; Burritt, R.L.; Sanagustín, M.V.; Moneva, J.M.; Tingey-Holyoak, J. Environmental reporting in the Spanish wind energy sector: An institutional view. J. Clean. Prod. 2013, 40, 199-211. [CrossRef]

3. Jenkins, H.; Yakovleva, N. Corporate social responsibility in the mining industry: Exploring trends in social and environmental disclosure. J. Clean. Prod. 2006, 14, 271-284. [CrossRef]

4. Wirth, H.; Kulczycka, J.; Hausner, J.; Koński, M. Corporate Social Responsibility: Communication about social and environmental disclosure by large and small copper mining companies. Resour. Policy 2016, 49, 53-60. [CrossRef]

5. The European Parliament; The Council of the European Union. Directive 2014/95/EU of the European Parlament and of the Council of 22 October 2014 Amending Directive 2013/34/EU as Regards Disclosure of Non-Financial and Diversity Information by Certain Large Undertakings and Groups. Available online: http: / / eur-lex.europa.eu/legal-content/EN/TXT/PDF/?uri=OJ:JOL_2014_330_R_0001\&from=EN (accessed on 25 January 2016).

6. Carroll, A.B. Corporate Social Responsibility: Evolution of a Definitional Construct. Bus. Soc. 1999, 38, 268-295. [CrossRef]

7. Eccles, R.G.; Krzus, M.P. One Report: Integrated Reporting for a Sustainable Strategy; John Wiley \& Sons: Hoboken, NJ, USA, 2010.

8. Jaworska, E. Zmiana Podejścia do Sprawozdawczości w Aspekcie Społecznej Odpowiedzialności Przedsiębiorstwa. Finanse, Rynki Finansowe, Ubezpieczenia. Zesz. Nauk. Uniw. Szczec. 2011, 668, 573-583.

9. Szczepankiewicz, E.I. Ewolucja sprawozdawczości przedsiębiorstw-Problemy zapewnienia porównywalności zintegrowanych raportów z zakresu zrównoważonego rozwoju i CSR. Finanse, Rynki Finansowe, Ubezpieczenia. Zesz. Nauk. Uniw. Szczec. 2014, 832, 135-148.

10. Szczepankiewicz, E.; Mućko, P. CSR Reporting Practices of Polish Energy and Mining Companies. Sustainability 2016, 8, 126. [CrossRef]

11. Pactwa, K.; Woźniak, J. Environmental reporting policy of the mining industry leaders in Poland. Resour. Policy 2017, 53, 201-207. [CrossRef]

12. Hilson, G.; Murck, B. Sustainable development in the mining industry: Clarifying the corporate perspective. Resour. Policy 2000, 26, 227-238. [CrossRef]

13. Nielsen, A.E.; Thomsen, C. Reporting CSR-What and how to say it? Corp. Commun. Int. J. 2007, 12, $25-40$. [CrossRef]

14. Jenkins, H. Corporate social responsibility and the mining industry: Conflicts and constructs. Corp. Soc. Responsib. Environ. Manag. 2004, 11, 23-34. [CrossRef]

15. Owen, J.R.; Kemp, D. Social licence and mining: A critical perspective. Resour. Policy 2013, 38, $29-35$. [CrossRef]

16. Hilson, G. Corporate Social Responsibility in the extractive industries: Experiences from developing countries. Resour. Policy 2012, 37, 131-137. [CrossRef]

17. Dilling, P. Reporting on Long-Term Value Creation-The Example of Public Canadian Energy and Mining Companies. Sustainability 2016, 8, 938. [CrossRef] 
18. Peck, P.; Sinding, K. Environmental and social disclosure and data richness in the mining industry. Bus. Strat. Environ. 2003, 12, 131-146. [CrossRef]

19. Ki-Hoon, L.; Herold, D.M.; Ae-Li, Y. Small and Medium Enterprises and Corporate Social Responsibility Practice: A Swedish Perspective. Corp. Soc. Responsib. Environ. Mgmt. 2016, 23, 88-99. [CrossRef]

20. Vormedal, I.; Ruud, A. Sustainability Reporting in Norway-An Assessment of Performance in the Context of Legal Demands and Socio-Political Drivers. Bus. Strat. Environ. 2009, 18, 207-222. [CrossRef]

21. Brammer, S.; Pavelin, S. Factors Influencing the Quality of Corporate Environmental Disclosure. Bus. Strat. Environ. 2008, 17, 120-136. [CrossRef]

22. Bryane, M. Corporate social responsibility in international development: An overview and critique. Corp. Soc. Responsib. Environ. Mgmt. 2003, 10, 115-128. [CrossRef]

23. Dobers, P.; Halme, M. Corporate Social Responsibility and Developing Countries. Corp. Soc. Responsib. Environ. Mgmt. 2009, 16, 237-249. [CrossRef]

24. Craig, D.; Michaela, R. Do Australian companies report environmental news objectively? An analysis of environmental disclosures by firms prosecuted successfully by the Environmental Protection Authority. Acc. Audit. Account. J. 1996, 9, 50-67. [CrossRef]

25. Cho, C.H.; Patten, D.M. The role of environmental disclosures as tools of legitimacy: A research note. Account. Organ. Soc. 2007, 32, 639-647. [CrossRef]

26. Keith, S. Mission impossible? Adopting a CSR-based business model for extractive industries in developing countries. Resour. Policy 2012, 37, 179-184. [CrossRef]

27. Wróbel, M. Raportowanie społecznej odpowiedzialności w Polsce w świetle unormowań dyrektywy parlamentu europejskiego i rady 2014/95/UE. Zesz. Nauk. Wyższej Szkoły Humanit. Zarz. 2016, 17, 83-94. [CrossRef]

28. Kepore, K.P.; Imbun, B.Y. Mining and stakeholder engagement discourse in a Papua New Guinea mine. Corp. Soc. Responsib. Environ. Manag. 2011, 18, 220-233. [CrossRef]

29. Macintyre, M.; Mee, W.; Solomon, F. Evaluating social performance in the context of an 'audit culture': A pilot social review of a gold mine in Papua New Guinea. Corp. Soc. Responsib. Environ. Manag. 2008, 15, 100-110. [CrossRef]

30. Kaczmarek, W.; Rożek, R. Historia poszukiwań i rozpoznania złóż rud miedzi na monoklinie przedsudeckiej w okresie powojennym. Pr. Naukowe Inst. Górn. Politech. Wroc. Stud. Mater. 2006, 117, 113-121.

31. Paździora, J. Old Copper Field in: History of KGHM Development; Polska Miedz, S.A., Hadrys, E., Mierzwa, L., Eds.; Monograph KGHM: Lubin, Poland, 2007; pp. 15-25.

32. Piątkowski, J. Introduction in: Environmental Protection; Polska Miedz, S.A., Mizera, A., Piatkowski, J., Eds.; Monograph KGHM: Lubin, Poland, 2007; pp. 841-845.

33. Report by KGHM, 2015. Available online: http://kghm.com/pl/ (accessed on 21 November 2016).

34. Report by CG PGE, 2015. Available online: http:/ / www.gkpge.pl/ (accessed on 21 November 2016).

35. Sinclair-Desgagné, B.; Gozlan, E. A theory of environmental risk disclosure. J. Environ. Econ. Manag. 2003, 45, 377-393. [CrossRef]

36. Bogacz, P. Trendy i wyzwania CSR a ich uwzględnienie w polskim górnictwie. Prz. Górn. 2016, 72, 16-19.

37. GRI G4, Sustainability Reporting Guidelines, Reporting Principles and Standard Disclosures, 2013. Available online: https:/ / www.globalreporting.org/resourcelibrary / GRIG4-Part1-Reporting-Principlesand-Standard-Disclosures.pdf (accessed on 31 October 2016).

38. GRI G4, Sector Disclosures, Mining and Metals, 2013. Available online: https://www.globalreporting.org/ resourcelibrary /GRI-G4-Mining-and-Metals-Sector-Disclosures.pdf (accessed on 5 December 2016).

39. Report by CG PGE, 2013. Available online: http:/ / www.gkpge.pl/ (accessed on 21 November 2016).

40. Report by CG PGE, 2014. Available online: http:/ / www.gkpge.pl/ (accessed on 21 November 2016).

41. Report by KGHM, 2013. Available online: http://kghm.com/pl/ (accessed on 21 November 2016).

42. Report by KGHM, 2014. Available online: http:/ / kghm.com/pl/ (accessed on 21 November 2016).

43. Journal of Laws. Geological and Mining Law, Act of 9 June 2011. Journal of Laws from 2016 Item 1131. Available online: http:/ / isap.sejm.gov.pl (accessed on 19 December 2016).

(C) 2017 by the authors. Licensee MDPI, Basel, Switzerland. This article is an open access article distributed under the terms and conditions of the Creative Commons Attribution (CC BY) license (http:/ / creativecommons.org/licenses/by/4.0/). 